\title{
Pengaruh Kompensasi, Motivasi Kerja dan Kepuasan Kerja Sebagai Variabel Intervening Terhadap Kinerja
}

\author{
Garaika \\ Sekolah Tinggi Ilmu Ekonomi Trisna Negara \\ Jln. M.P. Bangsa Raja No. 27 Belitang Kab. OKU Timur-Sumatera Selatan, Indonesia \\ Email:Garaika.TN@gmail.com
}

\begin{abstract}
ABSTRAK
Penelitian ini bertujuan untuk menguji apakah pengaruh terdapat pengaruh kompensasi,

Dikirim:

6 Februari 2020

Revisi:

17 Februari 2020

Diterima:

30 Maret 2020 motivasi kerja dan kepuasan kerja sebagai variabel intervening terhadap kinerja dosen dan tenaga kependidikan Sekolah Tinggi Ilmu Ekonomi Trisna Negara. Penelitian ini menggunakan jenis penelitian deskriptif dan kausal (causality) dalam menjelaskan pengaruh antar variabel kompensasi, motivasi kerja, kepuasan kerja, dan kinerja. Pada tahap analisis inferensial analisis data dibantu dengan program statistik menggunakan analisis dengan program Structural Equation Modeling (SEM) yaitu program computer analisis Smart-PLS. Populasi dari penelitian ini adalah para dosen dan tenaga kependidikan Sekolah Tinggi Ilmu Ekonomi Trisna Negara. Sampel ditentukan berdasarkan metode purpose sampling, dengan jumlah sampel sebanyak 100 orang guru dan karyawan. Teknik pengumpulan data menggunakan metoda penyebaran kuesioner. Kompensasi mempunyai pengaruh positif signifikan terhadap kepuasan kerja, motivasi kerja berpengaruh positif dan signifikan terhadap kepuasan kerja, kompensasi berpengaruh positif dan signifikan terhadap kinerja, motivasi kerja berpengaruh positif dan signifikan terhadap kinerja dan kepuasan kerja berpengaruh positif dan signifikan terhadap kinerja dosen dan tenaga kependidikan Sekolah Tinggi Ilmu Ekonomi Trisna Negara.
\end{abstract}

Kata Kunci : Kompensasi, Motivasi kerja, Kepuasan kerja dan Kinerja.

\section{Effect of Compensation, Work Motivation and Job Satisfaction as Intervening Variables on Performance}

\begin{abstract}
This study aims to examine whether the influence of compensation, work motivation, and job satisfaction as an intervening variable on the performance of lecturers and education staff of the Trisna State College of Economics. This study uses descriptive and causal research types (causality) in explaining the influence between compensation variables, work motivation, job satisfaction, and performance. In the inferential analysis phase, data analysis is assisted by a statistical program using analysis with the Structural Equation Modeling (SEM) program, which is the Smart-PLS computer analysis program. The population of this study is the lecturers and education staff of the Trisna Negara College of Economics. The sample was determined based on the purpose sampling method, with a total sample of 100 teachers and employees-data collection techniques using the method of distributing questionnaires. Compensation has a significant positive effect on job satisfaction, work motivation has a positive and significant effect on job satisfaction, compensation has a positive and significant effect on performance, work motivation has a positive and significant effect on performance and job satisfaction has a positive and significant effect on the performance of lecturers and Higher Education staff Sekolah Tinggi Ilmu Ekonomi Trsina Negara.
\end{abstract}

Keyword: Compensation, work motivation, job satisfaction and performance

Cara Sitasi :

Garaika. (2020). Pengaruh Kompensasi, Motivasi Kerja dan Kepuasan Kerja Sebagai Variabel Intervening Terhadap

Kinerja. Jurnal Ilmiah Manajemen dan Bisnis, 21(1), 28-4. https://doi.org/10.30596/jimb.v21i1.4181. 


\section{Jurnal Ilmiah Manajemen dan Bisnis}

Perubahan lingkungan yang semakin cepat dan tidak pasti, dengan ditandai oleh arus globalisasi, sehingga tingkat ketergantungan antar bangsa tidak dapat terhindarkan lagi. Dampak dari perubahan lingkungan dan arus globalisasi tersebut mengakibatkan peta kekuatan ekonomi dan iklim dunia bisnis diwarnai persaingan yang semakin ketat, yang menimbulkan ketidakpastian dalam dunia bisnis. Oleh karenanya, dunia bisnis harus berupaya lebih meningkatkan kemampuan dan ketangguhan dalam rangka memenangkan persaingan.

Tidak terkecuali pada dunia pendidikan. Dimana pendidikan merupakan suatu kebutuhan pokok yang diperlukan bagi setiap manusia dalam memperoleh ilmu dan wawasan. Pendidikan formal maupun nonformal merupakan sarana untuk membentuk karakter kepribadian anak. Oleh karena itu pendidikan dalam sekolah maupun lingkungan keluarga merupakan salah satu aset terpenting bagi setiap anak, yang nantinya diharapkan mampu membentuk pola perilaku dan wawasan anak.

Seiring dengan perkembangan ilmu dan teknologi yang terjadi di Indonesia, membuat semua bidang usaha yang ada di Indonesia mengalami kemajuan dan persaingan di semua bidang usaha, baik transportasi, makanan serta minuman, dan pendidikan. Kondisi persaingan di dunia pendidikan khususnya pendidikan tinggi sudah mulai dirasakan oleh seluruh perguruan tinggi di Indonesia, khsuusnya di wilayah Sumatera Selatan. Memang, kompetisi yang terjadi saat ini tidak lagi antar Pendidikan Tinggi swasta saja yang dihadapi, melainkan sudah amat terbuka termasuk Perguruan Tinggi unggulan dan Perguruan Tinggi Negeri.
Seiring berjalannya waktu permasalahan dan tantangan yang dihadapi oleh STIE Trisna Negara nampaknya tidak semakin bertambah ringan dan sederhana, melainkan cenderung berat dan komplek. Tidak saja dengan sesama pendidikan swasta, melainkan dengan pendidikan yang dikelolah oleh pemerintah, khususnya di Sumatera Selatan. Persaingan juga terjadi mulai dari fasilitas kampus, biaya pendidikan, kwalitas pendidikan maupun pelayanan yang diberikan Perguruan Tinggi merupakan bentuk persaingan yang sangat ketat.

Seiring berjalannya waktu, sampai dengan kemudian masalah terlihat dimana jumlah peningkatan mahasiswa tidak dibarengi dengan kinerja daripada dosen dan para tenaga kependidikan. Penilaian kinerja adalah bagian penting dari proses kegiatan seorang pegawai. Penilaian kinerja adalah sistem yang digunakan untuk menilai dan mengetahui kinerja pegawai. Tujuan dilakukannya penilaian kinerja adalah memberikan umpan balik kepada pegawai untuk meningkatkan produktivitas, dan sebagai dasar pengambilan kebijakan terhadap pegawai (Januari Ismi, 2015). Kinerja pegawai merupakan pencapaian yang dicapai oleh seorang pegawai dalam melaksanakan pekerjaannya sesuai dengan tanggung jawabnya. Kinerja pegawai diukur berdasarkan standar atau kriteria yang telah ditetapkan oleh perusahaan (Cravens, 2015). Oleh karena itu sistem gaji akan mendorong ketidakpuasan pegawai dan dapat muncul dalam bentuk kinerja yang rendah. Dari teori tersebut dapat digambarkan hubungan antara kompensasi, motivasi dan kinerja pegawai. 
(7) Umpan balik yang diberikan

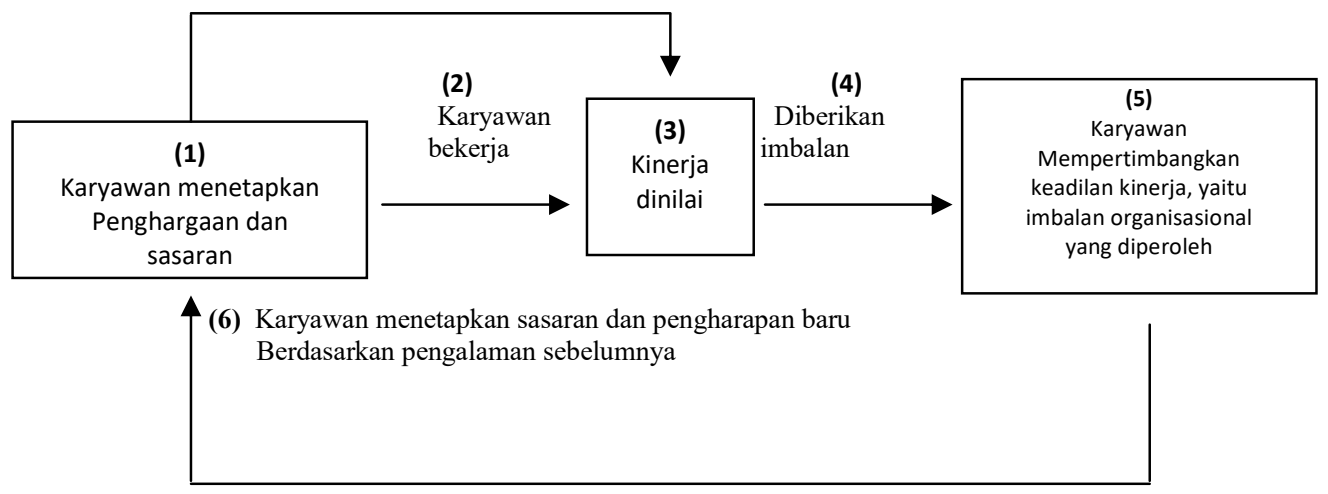

Gambar 1. Hubungan Kompensasi, Motivasi Dan Kinerja Karyawan.

Sumber : Henry Simamora dalam Yukl (2009)

Konsep teori di atas menggambarkan adanya hubungan kausal antara kompensasi yang rendah akan mempengaruhi motivasi dan diduga akan mempengaruhi kinerja guru dan pegawai. Salah satu upaya untuk meningkatkan mutu perguruan tinggi dilakukan dengan cara peningkatan kinerja dosen dan tenaga kependidikan karena dosen dan tenaga kependidikan merupakan tokoh sentral yang berhubungan langsung dengan mahasiswa melalui kegiatan proses belajar mengajar di kelas. Namun yang lebih perlu sebenarnya adalah daya dorong yang harus dimiliki oleh dosen dan tenaga kependidikan untuk meningkatkan motivasi kerja yang tinggi mengingat akan beban yang dipikulnya untuk memberikan lulusan yang bermutu.

Akan tetapi tidak bisa dipungkiri bahwa terdapat faktor lain yang bisa menyebabkan menurunnya kinerja para dosen dan tenaga kependidikan. Salah satunya adalah rendahnya kepuasan kerja dosen dan tenaga kependidikan STIE TN. Rendahnya kepuasan kerja yang dimiliki akan berpengaruh pada kinerja dosen dan tenaga kependidikan. Kepuasan kerja sangatlah penting untuk meningkatkan kinerja dosen dan tenaga kependidikan. Kinerja seseorang dapat diukur berdasarkan variable-variabel yang berhubungan dengannya. Apabila diantara salah satu variabel tidak tepat pengorganisasiannya maka akan mempengaruhi hasil dari kerja itu sendiri.

Kompensasi dapat diartikan dengan beberapa istilah, diantaranya: gaji, tunjangan atau bonus. Gaji merupakan balas jasa dalam bentuk uang yang diterima pegawai sebagai kontribusi telah ikut dalam mencapai tujuan perusahaan/organisasi (Afifah, 2017). Tingkat gaji sangat penting karena berkaitan dengan kemampuan organisasi untuk memikat atau mempertahankan pegawai dan mengetahui posisi kompetitif perusahaan. Kebijakan tingkat gaji yang sehat bertjuuan untuk memikat suplai tenaga kerja yang memadai, mempertahankan pegawai dan menghindari terjadinya tingkat perputaran pegawai yang mahal (Afifah, 2017).

Kompensasi adalah seluruh hadiah ekstrinsik yang diterima karyawan dalam bentuk upah, gaji, insentif maupun bonus dan beberapa tunjangan lainnya. Salah satu fenomena yang muncul dewasa ini adalah adanya kebijakan pemberian kompensasi yang cenderung masih belum sepenuhya sesuai dengan harapan pegawai sedangkan kompensasi itu sendiri adalah merupakan salah satu faktor untuk mendorong pegawai 
agar memiliki kinerja yang tinggi. Kompensasi adalah semua pendapatan yang berbentuk uang, barang langsung atau tidak langsung yang diterima karyawan sebagai imbalan atas jasa yang diberikan kepada perusahaan. (Fajar, 2010).

Kompensasi mempunyai dua aspek, pertama pembayaran uang langsung dalam bentuk upah, gaji, insentif, komisi dan bonus, dan kedua pembayaran tidak langsung dalam bentuk tunjangan keuangan seperti asuransi dan uang liburan yang dibayarkan perusahaan. Kompensasi terbagi menjadi dua, terdapat kompensasi langsung maupun kompensasi tidak langsung. Kompensasi langsung terdiri dari gaji, uang transport, tunjangan hari raya, uang lembur dan tunjangan langsung lainnya, Sedangkan kompensasi tidak langsung terdiri dari promosi jabatan, asuransi, tunjangan jabatan dan mutasi (Lina, 2016).

Kompensasi merupakan segala sesuatu yang diterima pegawai sebagai bentuk balas jasa atau kerja mereka yang berupa uang atau barang yang diberikan langsung maupun tidak langsung. Kompensasi pada umumnya bertujuan untuk kepentingan perusahaan, pegawai, masyarakat, dan bahkan pemerintah. Program kompensasi hendaknya ditetapkan berdasarkan prinsip keadilan, dan wajar berdasarkan undang-undang yang berlaku serta memperhatikan konsistensi internal maupun eksternal (Karomah, 2019).

Kompensasi dapat dikategorikan kedalam dua golongan besar yaitu: (1) Kompensasi langsung artinya adalah suatu balas jasa yang diberikan perusahaan kepada karyawan karena telah memberikan prestasinya demi kepentigan perusahaan. Kompensasi dapat diberikan secara langsung, misalnya berupa: upah atau gaji, insentif atau bonus, dan tunjangan jabatan, (2) Kompensasi tidak langsung adalah pemberian kompensasi kepada karyawan sebagai tambahan yang didasarkan kepada kebijakan pimpinan dalam rangka upaya meningkatkan kesejahteraan karyawan. Kompensasi belum pasti secara langsung berkaitan dengan pekerjaan yang dilakukan oleh karyawan, misalnya: tunjangan hari raya, tunjangan pensiun, dan tunjangan kesehatan (Karomah, 2019).

Motivasi dari bahasa latin movere yang berarti dorongan atau menggerakkan. Menurut. Motivasi adalah suatu kondisi yang mendorong atau menjadi sebab seseorang melakukan suatu perbuatan atau kegiatan, yang berlangsung secara sadar. Motivasi merupakan kegiatan yang mengakibatkan, dan memelihara perilaku manusia. (Fachreza, 2018).

Menurut Hasibuan dalam Fachreza (2018) motivasi merupakan hal yang menyebabkan, menyalurkan, dan mendukung perilaku manusia, supaya mau bekerja giat dan antusias mencapai hasil yang oprimal. Manajer perlu memahami proses psikologis ini apabila mereka ingin berhasil membina pekerja menuju pada penyelesaian sasaran organisasi.

Sedangkan Robbins dalam Setiawan (2015) motivasi sebagai proses yang menyebabkan intensitas, arah dan usaha terus menerus individu menuju pencapaian tujuan. Intensitas menunjukkan seberapa keras seseorang berusaha. Tetapi intensitas tinggi tidak mungkin mengarah kepada hasil kinerja yang baik, kecuali usaha dilakukan dalam arah menguntungkan organisasi. Karena harus dipertimbangkan kualitas usaha maupun intensitasnya. Motivasi mempunyai dimensi usaha terus menerus. Motivasi bisa digunakan sebagai indikator berapa lama karyawan dapat menjaga kinerja mereka. Karyawan yang termotivasi akan mengerjakan pekerjaannya sebaik mungkin.

Menurut Wexley dalam Daryanti (2013) motivasi merupakan pemberian motif atau dapat pula diartikan sebagai sesuatu hal atau keadaan menjadi yang bisa menjadi motif. Motivasi adalah serangkaian proses yang membangkitkan, mengarahkan dan menjaga perilaku karyawan dalam mencapai tujuannya. Membangkitkan dalam hal ini adalah mendorong atau member energi pada 
tindakan. Motivasi berkaitan dengan pilihan yang dilakukan dan arah perilaku para karyawan. Sedangkan perilaku menjaga atau memelihara adalah berapa lama karyawan tersebut akan berusaha dalam mencapai tujuan mereka.

Menurut Hasibuan dalam Saputri (2014), bahwa motivasi kerja karyawan dipengaruhi oleh kebutuhan akan berprestasi, kebutuhan akan afiliasi, kebutuhan akan kompetensi dan kebutuhan akan kekuasaan. Kemudian dari faktor kebutuhan tersebut diturunkan menjadi indikator-indikator untuk mengetahui tingkat motivasi kerja pada karyawan, yaitu: (1) kebutuhan akan berprestasi, yaitu suatu keinginan untuk mengatasi/mengalahkan suatu tantangan, untuk kemajuan, dan pertumbuhan. (2) kebutuhan akan afiliasi, yaitu dorongan untuk melakukan hubungan dengan orang lain. (3) kebutuhan akan kompetensi, yaitu dorongan untuk melakukan pekerjaan yang bermutu, dan (4) kebutuhan akan kekuasaan, yaitu dorongan yang dapat mengendalikan suatu keadaan.

Robbins and Judge dalam Damayanti (2018) mendefinisikan kepuasan kerja sebagai perasaan positif pada suatu pekerjaan, yang merupakan dampak/hasil evaluasi dari berbagai aspek pekerjaan tersebut. Kepuasan kerja adalah keadaan emosional yang menyenangkan atau tidak menyenangkan bagi karyawan memandang pekerjaan mereka. Kepuasan kerja mencerminkan perasaan seseorang terhadap pekerjaannya. Karyawan merupakan asset perusahaan yang sangat berharga yang harus dikelola dengan baik oleh perusahaan agar dapat memberikan kontribusi yang optimal. Salah satu yang harus menjadi perhatian utama perusahaan adalah kepuasan kerja para karyawannya, karena karyawan yang dalam bekerja mereka tidak merasakan kenyamanan, kurang dihargai, tidak bisa mengembangkan segala potensi yang mereka miliki, maka secara otomatis karyawan tidak dapat focus dan berkonsentrasi secara penuh terhadap pekerjaannya (Burhanudin, 2012).

Luthans mengatakan kepuasan kerja adalah keadaan yang menyenangkan atau emosi yang bersifat positif dihasilkan dari penilaian pekerjaan dan atau pengalaman kerja seorang pegawai. Kepuasan kerja diperoleh berdasarkan persepsi pegawai mengenai pekerjaan mereka. Lima aspek (1) kepuasan kerja diukur dengan pekerjaan itu sendiri yang berhubungan dengan tanggung jawab, minat dan pertumbuhan; (2) kualitas supervisi yang terkait dengan bantuan teknis dan dukungan sosial; (3) hubungan dengan rekan kerja yang berkaitan dengan harmoni sosial dan respek; (4) kesempatan promosi yang terkait dengan kesempatan untuk pengembangan lebih jauh; (5) dan pembayaran yang terkait dengan pembayaran yang memadai dan persepsi keadilan (Kristianto, 2011).

Factor-faktor yang mempengaruhi kepuasan kerja antara lain: (1) faktor psikologis; merupakan faktor yang berhubungan dengan kejiwaan meliputi minat, ketentraman dalam bekerja, sikap terhadap kerja, bakat dan keterampilan, (2) faktor sosial: merupakan faktor yang berhubungan dengan interaksi sosial antar karyawan dengan atasan, (3) faktor fisik: merupakan faktor yang berhubungan dengan kondisi fisik karyawan, meliputi jenis pekerjaan, pengaturan waktu dan waktu istirahat, perlengkapan kerja, keadaan ruangan, suhu, penerangan, pertukara udara, kondisi kesehatan karyawan, umur dan sebagainya, dan (4) faktor finansial: merupakan faktor yang berhubungan jaminan serta kesejahteraan karyawan, yang meliputi sistem dan haji, jaminan sosial, macammacam tunjangan, fasilitas yang diberikan, promosi dan sebagainya. (Kristianto, 2011).

Kinerja pegawaii adalah prestasi yang dicapai dalam melaksanakan tugasnya sesuai dengan tanggung jawabnya. Kinerja pegawai diukur berdasarkan kriteria yang ditetapkan oleh perusahaan (Cravens, 2015). Kinerja 
pegawai adalah hasil yang dicapai seorang pegawai di tempat kerja (Cardy 2004). Kinerja pegawai adalah prestasi dalam bentuk kualitas maupun kuantitas oleh pegawai yang telah melaksanakan tugasnya sesuai dengan tanggung jawab yang diberikan. Perusahaan juga perlu melihat kinerja pegawai sebagai isu strategis dan juga sebagai alat untuk membantu mencapai keunggulan kompetitif perusahaan (Djastuti 2010).

Menurut Jimoh, (2008) menyatakan kinerja pegawai adalah tindakan, perilaku dan hasil yang dapat diukur dimana pegawai terikat dengan tujuan organisasi dan berkontribusi pada tujuan organisasi. Menurut Thompson dalam Jimoh, (2008), untuk mengukur kinerja pegawai diperlukan pengamat yang membuat keputusan penilaian terhadap kecenderungan perilaku orang yang dievaluasi yang berhubungan dengan kontribusi pada tujuan organisasi. Kinerja karyawan dapat diukur dengan kuantitas, kualitas, efisiensi, standar professional, kemampuan, penilaian, ketepatan, pengetahuan, dan kreativitas. Indikator dari kinerja karyawan adalah faktor kualitas kerja; kuantitas; pengetahuan; keandalan; dan kerjasama (Kristianto, 2011).

Berdasarkan uraian di atas, maka dapat disimpulkan pengertian kinerja adalah prestasi atau hasil kerja secara kuantitatif dan kualitatif yang dicapai seseorang pegawai dalam melaksanakan tugas organisasi berdasarkan wewenang dan tanggung jawab yang diberikan kepadanya sehingga kinerja dapat diukur menggunakan alat ukur tertentu.

Pada penelitian ini dimensi kinerja pegawai adalah : 1) Dimensi kuantitas kerja, meliputi indikator: a. Penyusunan rencana kerja, b. Ketepatan waktu pertanggung jawaban laporan keuangan. 2) Dimensi kualitas kerja, meliputi indikator : a. Kualitas pelayanan kepada anggota, b. Upaya pengembangan unit-unit usaha. 3) Dimensi luasnya pengetahuan, indikator meliputi :a. pengetahuan prinsip-prinsip koperasi, b. Pengatahuan sistem administrasi koperasi. 4) Dimensi keaslian gagasan, dan kerjasama, indikator : a. Kreativitas tinggi, b. Kerja sama dengan sesama pegawai kompak. 5) Dimensi semangat dan kepribadian, indikator: a. Semangat menyelesaikan suatu pekerjaan, b. Mewujudkan keperibadian sebagai tauladan. Hipotesis penelitian ini adalah ada pengaruh kompensasi terhadap kepuasan kerja, ada pengaruh motivasi kerja terhadap kepuasan kerja, ada pengaruh kompensasi terhadap kinerja, ada pengaruh motivasi kerja terhadap kinerja dosen, ada pengaruh kepuasan kerja terhadap kinerja dosen dan tenaga kependidikan Sekolah Tinggi Ilmu Ekonomi Trisna Negara, Kerangks konseptual dapat dilihat pada Gambar 1.

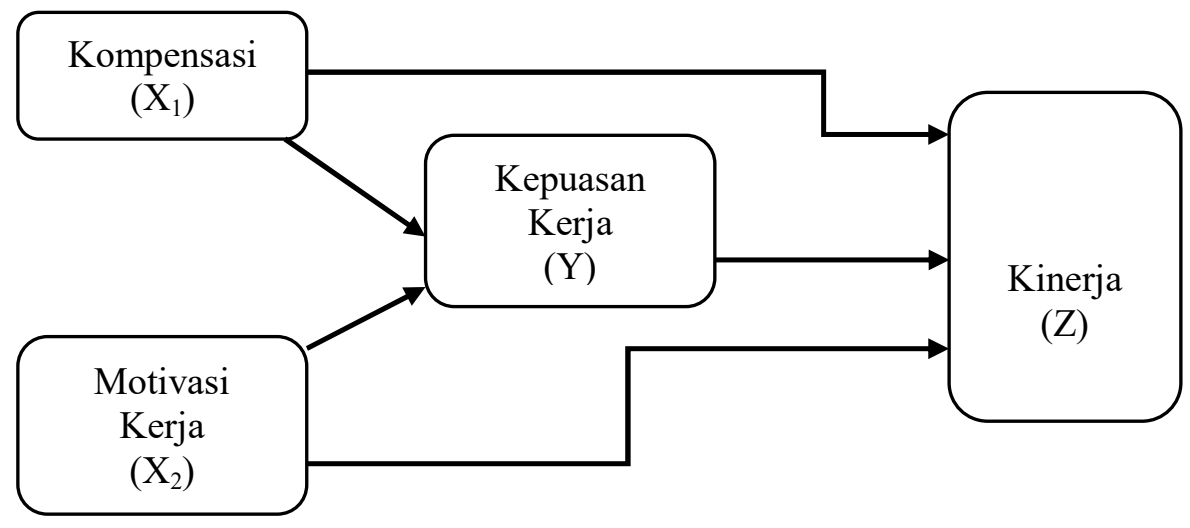

Gambar 1. Kerangka Penelitian 


\section{METODE}

Penelitian ini menggunakan jenis penelitian deskriptif dan kausal dalam menjelaskan pengaruh antar variabel kompensasi, motivasi kerja, kepuasan kerja, dan kinerja. Jenis penelitian ini dapat digolognkan penelitian kuantitatif asosiatif kausal. Sugiyono (2016) penelitian kuantitatif digunakan meneliti populasi atau sampel tertentu, teknik pengambilan sampel dan pada umumnya dilakukan secara rendom, pengumpulan data menggunakan instrumen penelitian, analisis data bersifat kuantitatif dengan tujuan untuk menguji hipotesis yang telah ditetapkan. Sugiyono (2016) juga mengatakan bahwa rumusan masalah asosiatif adalah satu pertanyaan penelitian yang bersifat menanyakan hubungan antara dua variabel atau lebih.

Populasi adalah keseluruhan subjek penelitian. Apabila seorang peneliti ingin meneliti semua elemen yang ada dalam wilayah penelitian, maka penelitiannya merupakan penelitian populasi. Studi penelitiannya juga disebut studi populasi atau

\section{HASIL DAN PEMBAHASAN}

Analisis Model Struktural atau SEM (Structural Equation Modeling).
Hubungan kausal adalah hubungan yang bersifat sebab akibat, sehingga kemudian terdapat variabel independen atau variabel yang mempengaruhi dan variabel dependen atau variabel yang dipengaruhi.

Dalam penelitian ini analisis data secara inferensial statistik menggunalan analisis dengan program Structural Equation Modeling (SEM), diibantu program analisis Smart-PLS dengan terlebih dahulu melakukan uji validitas dan reliabilitas untuk setiap item pernyataan mengenai variabel yang diteliti. Selanjutnya setelah diketahui semua hasil pengolahan data akan dilakukan pembahasan mengenai hasil pengolahan dan yang terakhir adalah menarik kesimpulan yang didasarkan pada hasil analisis tersebut.

studi sensus. Berdasarkan hal tersebut, maka populasi dalam penelitian ini adalah dosen dan tenaga kependidikan Sekolah Tinggi Ilmu Ekonomi Trisna Negara yang berjumlah 99 responden (Suharsimi, 2002).

Teknik pengolahan data menggunakan SEM berbasis Smart Partial Least Square (PLS) diperoleh dari analisis awal dengan sebagai berikut :

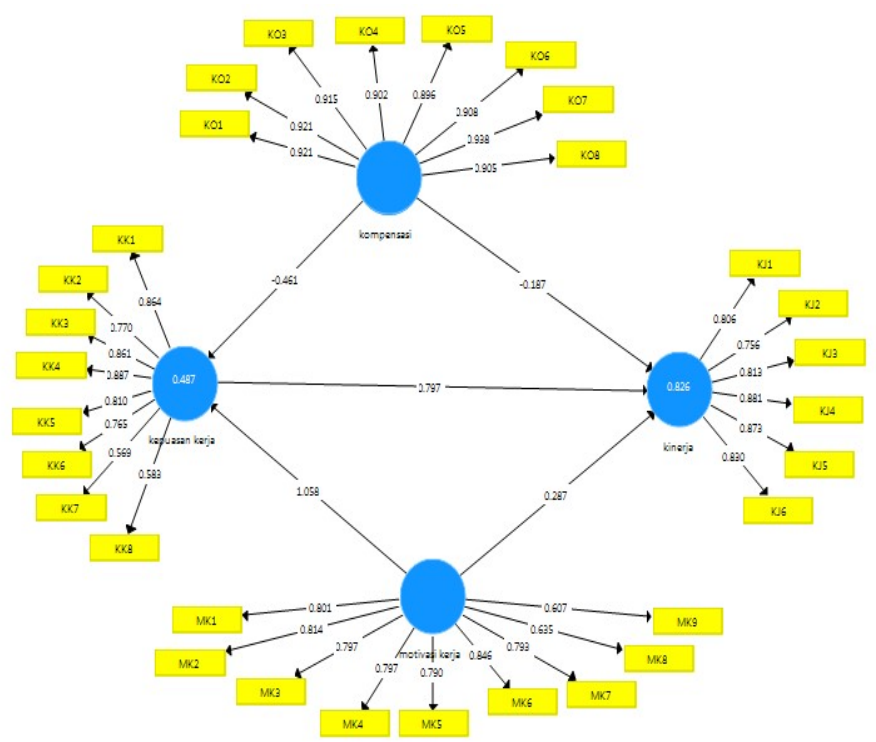

Gambar 2. Hasil Olah PLS (PLS_Algorithm) 


\section{Jurnal Ilmiah Manajemen dan Bisnis}

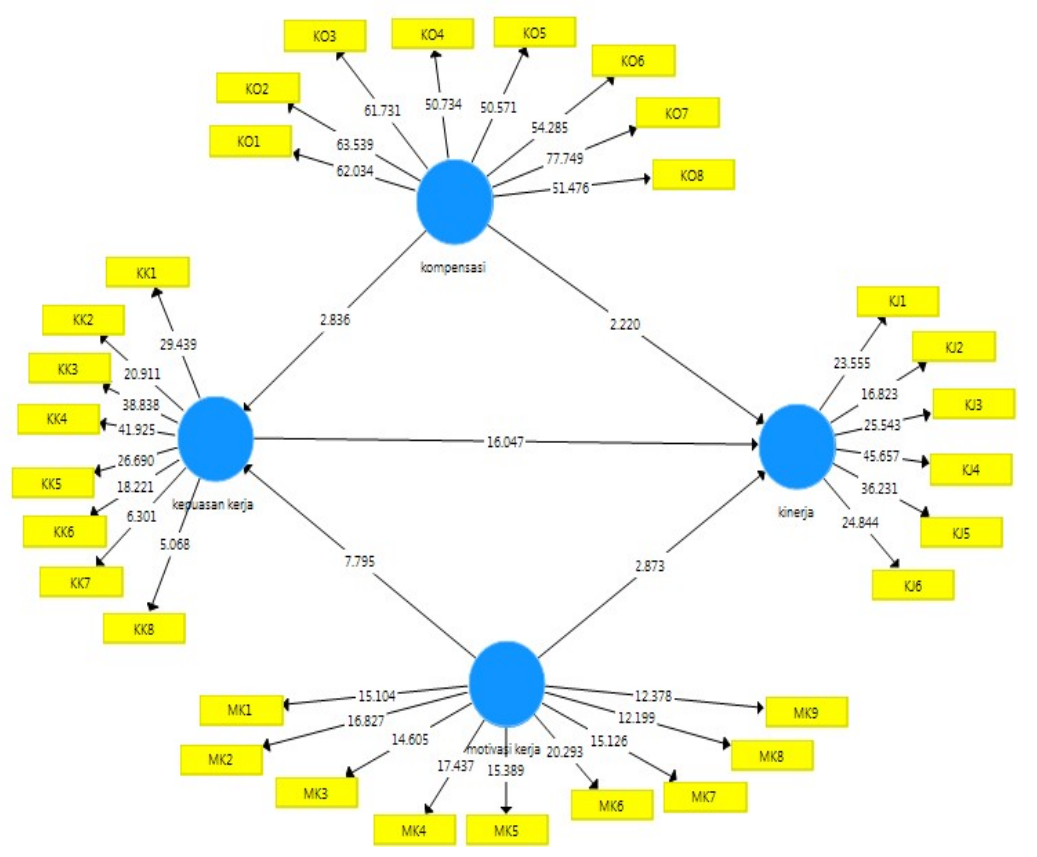

Gambar 3. Hasil Olah PLS (PLS_Bootstrapping)

Tabel 1. Uji Validitas

\begin{tabular}{|c|c|c|c|c|c|}
\hline Kode & Kinerja & Kompensasi & $\begin{array}{c}\text { Motivasi } \\
\text { Kerja }\end{array}$ & $\begin{array}{c}\text { Kepuasan } \\
\text { Kerja }\end{array}$ & Ket. \\
\hline (1) & (2) & (3) & (4) & (5) & (6) \\
\hline KJ1 & 0.806 & - & - & - & Valid \\
\hline KJ2 & 0.756 & - & - & - & Valid \\
\hline KJ3 & 0.813 & - & - & - & Valid \\
\hline KJ4 & 0.881 & - & - & - & Valid \\
\hline KJ5 & 0.873 & - & - & - & Valid \\
\hline KJ6 & 0.830 & - & - & - & Valid \\
\hline K01 & - & 0.921 & - & - & Valid \\
\hline KO2 & - & 0.921 & - & - & Valid \\
\hline KO3 & - & 0.915 & - & - & Valid \\
\hline KO4 & - & 0.902 & - & - & Valid \\
\hline KO5 & - & 0.896 & - & - & Valid \\
\hline KO6 & - & 0.908 & - & - & Valid \\
\hline KO7 & - & 0.938 & - & - & Valid \\
\hline KO8 & - & 0.905 & - & - & Valid \\
\hline MK1 & - & - & 0.801 & - & Valid \\
\hline MK2 & - & - & 0.814 & - & Valid \\
\hline MK3 & - & - & 0.797 & - & Valid \\
\hline MK4 & - & - & 0.797 & - & Valid \\
\hline MK5 & - & - & 0.790 & - & Valid \\
\hline MK6 & - & - & 0.846 & - & Valid \\
\hline MK7 & - & - & 0.793 & - & Valid \\
\hline MK8 & - & - & 0.635 & - & Valid \\
\hline MK9 & - & - & 0.607 & - & Valid \\
\hline KK1 & - & - & - & 0.864 & Valid \\
\hline KK2 & - & - & - & 0.770 & Valid \\
\hline KK3 & - & - & - & 0.861 & Valid \\
\hline KK4 & - & - & - & 0.887 & Valid \\
\hline KK5 & - & - & - & 0.810 & Valid \\
\hline KK6 & - & - & - & 0.765 & Valid \\
\hline KK7 & - & - & - & 0.569 & Valid \\
\hline KK8 & - & - & - & 0.583 & Valid \\
\hline
\end{tabular}




\section{Jurnal Ilmiah Manajemen dan Bisnis}

ISSN 1693-7619 (Print) I ISSN 2580-4170 (Online) | http://jurnal.umsu.ac.id/index.php/mbisnis

Pada Tabel 1, menunjukkan bahwa loading factor memberikan nilai di atas nilai yang disarankan yaitu sebesar 0,5. Berarti semua indikator yang terdapat dalam variabel penelitian yang dipergunakan dalam penelitian ini adalah valid atau telah memenuhi convergent validity.

Tabel 2. Uji Reliabilitas

\begin{tabular}{clccc}
\hline No. & Variabel & $\begin{array}{c}\text { Average Variance Extracted } \\
\text { (AVE) }\end{array}$ & $\begin{array}{c}\text { Composite } \\
\text { Reliability }\end{array}$ & Cronbach Alpha \\
\hline \multirow{2}{*}{1} & Kompensasi (X1), & 0.834 & 0.976 & 0.972 \\
& & $($ reliabel) & 0.928 & $($ reliabel) \\
2 & Motivasi Kerja (X2) & 0.591 & 0.917 \\
& & $($ reliabel) & $($ reliabel) & $($ reliabel) \\
& & 0.597 & 0.920 & 0.900 \\
$($ Kepuasan Kerja (Y) & (tidak reliabel) & 0.929 & 0.908 \\
& & 0.685 & $($ reliabel) \\
4 & Kinerja (Z) & (reliabel) & & $($ reliabel) \\
\hline
\end{tabular}

Dari hasil uji reliabilitas di atas menunjukkan bahwa semua variabel penelitian sudah menunjukkan sebagai pengukur yang fit, sehingga kemudian semua variabel yang diteliti dari semua item pertanyaan yang akan digunakan memiliki tingkat reliabilitas yang baik. Outer Model juga bisa dilihat dari nilai composite reliability dari nilai cronbach alpha, hasil composite reliability seperti pada gambar di atas. Composite reliability untuk masing masing konstruk sangat baik karena bernilai di atas 0,80 , disamping itu juga dapat dilihat dari nilai cronbach alpha seperti pada Tabel 2, semua nilai cronbach alpha bernilai di atas 0,70. Validitas dari masing masing konstruk diuji dengan Average Variance Extracted (AVE), konstruk dengan validitas baik karena bernilai lebih dari 0,50 (Ghozali.2015).

Tabel 3. $R$ Square

\begin{tabular}{lc}
\hline \multicolumn{1}{c}{ Variabel } & R Square \\
\hline Kepuasan Kerja $(\mathrm{Y})$ & 0,487 \\
Kinerja $(\mathrm{Z})$ & 0,826 \\
\hline
\end{tabular}

Tabel 3, menunjukkan nilai $\mathrm{R}$-square variabel kepuasan kerja sebesar 0.487 artinya variabilitas kepuasan kerja yang dapat dijelaskan oleh kompensasi dan motivasi kerja sebesar $48,7 \%$ dan variabel kinerja sebesar 0.826 artinya variabilitas kinerja yang dapat dijelaskan oleh kompensasi, motivasi kerja dan kepuasan kerja sebesar $82,6 \%$. Semakin tinggi nilai $R$ square, maka semakin besar kemampuan variabel independen tersebut dapat menjelaskan variabel dependen sehingga semakin baik persaman struktural.

Tabel 4. Path Coefficient

\begin{tabular}{clcccc}
\hline No. & \multicolumn{1}{c}{ Path Coefficient } & $\begin{array}{c}\text { Original } \\
\text { Sample }\end{array}$ & $\begin{array}{c}\text { Sample } \\
\text { Mean }\end{array}$ & T Stat & p Values \\
\hline 1 & $\begin{array}{l}\text { Kompensasi (X1) } \rightarrow \\
\text { Kerpuasan Kerja (Y) } \\
\text { Motivasi Kerja (X2) } \rightarrow\end{array}$ & 0.461 & 0.451 & 2.836 & 0.005 \\
3 & $\begin{array}{l}\text { Kepuasan Kerja (Y) } \\
\text { Kompensasi (X1) } \rightarrow\end{array}$ & 0.185 & 1.054 & 7.795 & 0.000 \\
4 & $\begin{array}{l}\text { Kinerja (Z) } \\
\text { Motivasi Kerja (X2 } \rightarrow\end{array}$ & 0.287 & 0.277 & 2.873 & 0.004 \\
5 & $\begin{array}{l}\text { Kinerja (Z) } \\
\text { Kepuasan Kerja (Y) } \rightarrow\end{array}$ & 0.797 & 0.798 & 16.047 & 0.000 \\
\hline
\end{tabular}




\section{Pembahasan \\ Pengaruh Kompensasi Terhadap Kepuasan kerja}

Pengujian terhadap hipotesis pertama yang menyatakan bahwa kompensasi mempunyai pengaruh positif signifikan terhadap kepuasan kerja dosen dan tenaga kependidikan terbukti dengan nilai t statistik adalah $2.836 \geq 1.96$. Hal ini menunjukkan bahwa adanya imbalan atau penghargaan kepada dosen dan tenaga kependidikan yang berprestasi akan membuat mereka merasakan kepuasan, sehingga akan mampu meningkatkan produktivitas maupun kinerja dosen dan tenaga kependidikan Sekolah Tinggi Ilmu Ekonomi Trsina Negara. Hasil penelitian ini mendukung pendapat oleh Hasibuan (2007) bahwa kepuasan kerja dalam pekerjaan adalah kepuasan kerja yang dinikmati dalam pekerjaan dengan memperoleh pujian hasil kerja, penempatan, perlakuan, peralatan dan suasana lingkungan kerja yang baik. Karyawan yang lebih suka menikmati kepuasan kerja dalam pekerjaan akan lebih mengutamakan pekerjaan daripada balas jasa walaupun balas jasa itu penting. Hasil penelitian ini selaras dengan penelitian terdahulu oleh Suputra, (2016), dimana hasil penelitiannya menunjukkan bahwa 1) kepuasan kerja berpengaruh positif signifikan terhadap motivasi kerja karyawan, 2) dukungan organisasional berpengaruh positif signifikan terhadap motivasi kerja karyawan, dan 3) gaya kepemimpinan transformasional berpengaruh positif signifikan terhadap motivasi kerja karyawan.

\section{Pengaruh Motivasi Kerja Terhadap Kepuasan kerja}

Pengujian terhadap hipotesis kedua yang menyatakan bahwa motivasi kerja mempunyai pengaruh positif signifikan terhadap kepuasan kerja dosen dan tenaga kependidikan terbukti dengan nilai t statistik adalah $7.795 \geq 1.96$. Pengaruh positif dari motivasi kerja tersebut menunjukkan bahwa pemberian motivasi kerja pada dosen dan tenaga kependidikan Sekolah Tinggi Ilmu Ekonomi Trsina Negara akan meningkatkan kepuasan kerja sehingga diharapkan akan meningkatkan kinerja. Hasil dari penelitian ini mendukung pendapat Wibowo (2014) bahwa teknik memotivasi harus dapat memastikan bahwa lingkungan dimana karyawan bekerja memenuhi sejumlah kebutuhan manusia yang penting. Temuan ini juga sesuai dengan hasil penelitian terdahulu oleh Afifah, (2017), hasil penelitiannya menunjukkan bahwa kepuasan kerja karyawan memiliki pengaruh signifikan terhadap motivasi kerja karyawan, begitu juga dengan motivasi kerja karyawan memiliki pengaruh signifikan terhadap kinerja karyawan.

\section{Pengaruh Kompensasi Terhadap Kinerja}

Pengujian terhadap hipotesis ketiga yang menyatakan bahwa kompensasi mempunyai pengaruh positif signifikan terhadap kinerja dosen dan tenaga kependidikan terbukti dengan nilai t statistik adalah $2.220 \geq 1.96$. Pengaruh positif dari kompensasi tersebut menunjukkan bahwa pemberian kompensasi dapat meningkatkan kinerja dosen dan tenaga kependidikan Sekolah Tinggi Ilmu Ekonomi Trsina Negara. Menururt Fajar (2010) Kompensasi adalah seluruh extrinsic reward yang diterima oleh karyawan dalam bentuk upah atau gaji, insentif atau bonus dan beberapa tunjangan. Dengan pemberian kompensasi akan membuat para karyawan menjadi berkinerja tinggi. Temuan ini sesuai dengan hasil penelitian yang dilakukan oleh Mundakir (2018), hasil penelitiannya menunjukkan kompensasi dan motivasi kerja berpengaruh terhadap kepuasan kerja pegawai. Kompensasi secara langsung tidak berpengaruh terhadap kinerja pegawai. Sedangkan motivasi kerja dan kepuasan kerja berpengaruh signifikan terhadap kinerja pegawai. Kompensasi dan motivasi kerja secara tidak langsung melalui kepuasan kerja 
berpengaruh signifikan terhadap kinerja pegawai.

\section{Pengaruh Motivasi Kerja Terhadap Kinerja}

Pengujian terhadap hipotesis keempat yang menyatakan bahwa motivasi kerja mempunyai pengaruh positif signifikan terhadap kinerja dosen dan tenaga kependidikan Sekolah Tinggi Ilmu Ekonomi Trisna Negara terbukti dengan nilai t statistik adalah $2.873 \geq 1.96$. Pengaruh positif dari motivasi kerja tersebut menunjukkan bahwa memotivasi dosen dan tenaga kependidikan dapat meningkatkan kinerja dosen dan tenaga kependidikan Sekolah Tinggi Ilmu Ekonomi Trsina Negara. Menurut Robbins dalam Widodo (2016) menyatakan motivasi sebagai proses yang menyebabkan intensitas, arah dan usaha terus menerus individu menuju pencapaian tujuan. Intensitas menunjukkan seberapa keras seseorang berusaha. Tetapi intensitas tinggi tidak mungkin mengarah kepada hasil kinerja yang baik, kecuali usaha dilakukan dalam arah menguntungkan organisasi. Temuan ini sesuai dengan hasil penelitian yang dilakukan oleh Gunawan (2018). Hasil penelitian ini menyatakan bahwa pengalaman kerja, kompensasi dan motivasi secara simultan berpengaruh terhadap kinerja karyawan pada PT. Unilever. Tbk di Manado, tetapi secara parsial kepuasan kerja tidak berpengaruh signifikan terhadap kinerja karyawan.

\section{Pengaruh Kepuasan Kerja Terhadap Kinerja}

Pengujian terhadap hipotesis kelima yang menyatakan bahwa kepuasan kerja mempunyai pengaruh positif signifikan terhadap kinerja dosen dan tenaga kependidikan Sekolah Tinggi Ilmu Ekonomi Trisna Negara terbukti dengan nilai t statistik adalah $16.047 \geq 1.96$. Pengaruh positif dari kepuasan kerja tersebut menunjukkan bahwa meningkatkan kepuasan kerja para dosen dan tenaga kependidikan dapat meningkatkan kinerja dosen dan tenaga kependidikan
Sekolah Tinggi Ilmu Ekonomi Trsina Negara. Menurut Robbins dalam Rahmatullah, (2012) hubungan kepuasan kerja dengan kinerja lebih tepat disebut 'mitos manajemen' dan sulit untuk menetapkan ke arah mana hubungan sebab akibat diantara keduanya. Namun dari berbagai penelitian ditemukan bukti bahwa organisasi yang memiliki karyawan yang lebih puas cenderung lebih efektif dibandingkan dengan organisasi yang memiliki karyawan yang kurang puas. Temuan ini sesuai dengan hasil penelitian yang dilakukan oleh Prayuginingsih (2011) hasil penelitiannya menjelaskan bahwa kepuasan kerja dan motivasi kerja berpengaruh signifikan dengan koefisien determinasi sekitar 0.5051. Variabel kepuasan kerja mampu memediasi variabel kompensasi dan motivasi kerja terhadap kinerja KSK BPS Provinsi DIY. Meskipun untuk variabel motivasi kerja terhadap kinerja secara utuh dimediasi oleh variabel kepuasan. Sedangkan besarnya koefisien pengaruh antar konstruk yang dihipotesiskan ditunjukkan oleh nilai koefisien jalurnya. Pengaruh terbesar adalah kepuasan kerja terhadap kinerja sebesar 0.797, dan pengaruh terkecil adalah kompensasi terhadap kinerja sebesar 0.187.

\section{SIMPULAN}

Berdasarkan hasil penelitian dapat disimpulkan: pertama, kompensasi mempunyai pengaruh positif signifikan terhadap kepuasan kerja dosen dan tenaga kependidikan Sekolah Tinggi Ilmu Ekonomi Trisna Negara, dimana semakin baik pemberian kompensasi yang dirasakan oleh dosen dan tenaga kependidikan maka kepuasan kerja yang dirasakan oleh dosen dan tenaga kependidikan tersebut juga akan semakin tinggi. Kedua, motivasi kerja berpengaruh positif dan signifikan terhadap kepuasan kerja dosen dan tenaga kependidikan Sekolah Tinggi Ilmu Ekonomi Trisna Negara sehingga semakin baik motivasi kerja yang diberikan akan dapat mempengaruhi kepuasan kerja dosen dan 


\section{Jurnal Ilmiah Manajemen dan Bisnis}

tenaga kependidikan Sekolah Tinggi Ilmu Ekonomi Trisna Negara. Ketiga, kompensasi berpengaruh positif dan signifikan terhadap kinerja dosen dan tenaga kependidikan Sekolah Tinggi Ilmu Ekonomi Trisna Negara, sehingga disimpulkan bahwa pemberian kompensasi kepada dosen dan tenaga kependidikan yang berprestasi akan meningkatkan kinerja dosen dan tenaga kependidikan Sekolah Tinggi Ilmu Ekonomi Trisna Negara. Keempat, motivasi kerja berpengaruh positif dan signifikan terhadap kinerja dosen dan tenaga kependidikan Sekolah Tinggi Ilmu Ekonomi Trisna Negara. Kondisi ini menunjukkan bahwa semakin banyak motivasi yang diberikan maka para dosen dan tenaga kependidikan Sekolah Tinggi Ilmu Ekonomi Trisna Negara akan berkinerja lebih baik. Kelima, kepuasan kerja berpengaruh positif dan signifikan terhadap kinerja dosen dan tenaga kependidikan Sekolah Tinggi Ilmu Ekonomi Trisna Negara. Hal ini mempunyai arti bahwa semakin tinggi kepuasan kerja para dosen dan tenaga kependidikan, maka mereka akan semakin berkinerja lebih baik, sehingga tujuan dari visi dan misi Sekolah Tinggi Ilmu Ekonomi Trisna Negara akan semakin tercapai.

Saran dari penelitian ini adalah untuk lebih meningkatkan kinerja dosen dan tenaga kependidikan Sekolah Tinggi Ilmu Ekonomi Trisna Negara. Dalam artian bahwa pimpinan dan pihak terkait perlu memberikan perhatian lebih terhadap upaya-upaya untuk menciptakan dan menumbuhkan rasa kepuasan kerja para dosen dan tenaga kependidikan Sekolah Tinggi Ilmu Ekonomi Trisna Negara. Diantara ketiga variabel yang berpengaruh terhadap kinerja tersebut diketahui bahwa variabel kepuasan kerja yang paling besar pengaruhnya terhadap kinerja, untuk itu perlu dilakukan upaya untuk meningkatkan kondisi yang memberikan kepuasan kerja dosen dan tenaga kependidikan, diantaranya memberikan rasa ketentraman dalam bekerja, meningkatkan keterampilan melalui pelatihan-pelatihan, menjalin hubungan antar dosen dan tenaga kependidikan, hubungan antara dosen dengan pimpinan, memberikan pekerjaan pada orang yang tepat, memberikan perlengkapan yang memadai untuk dosen dan tenaga kependidikan dalam bekerja, memberikan gaji yang layak dan memberikan tunjangantunjangan yang dapat membantu klehidupan layak para dosen dan tenaga kependidikan Sekolah Tinggi Ilmu Ekonomi Trisna Negara.

\section{REFERENSI}

Afifah Thara, Al Musadieq Mochammad, (2017). Pengaruh Kepuasan Kerja Terhadap Motivasi Kerja dan Dampaknya terhadap Kinerja (Studi pada Karyawan PT. Pertamina Geothermal Energy Kantor Pusat Jakarta). Jurnal Administrasi Bisnis (JAB), 47(1), 122-129.

Lina, (2016). Pengaruh Penilaian Kinerja terhadap Kinerja Karyawan dengan Budaya Organisasi sebagai Variabel Intervening, Jurnal Akuntansi, 8(2), 214-224.

Burhanuddin Wahab, R. (2012). Pengaruh Kepuasan Kerja dan Motivasi Kerja terhadap Kinerja Karyawan pada PT. Bank Mandiri (Persero) Tbk. Makassar. FEB Universitas Hasanuddin, Makassar.

Fajar, Mukti. (2010). Tanggung Jawab Sosial Perusahaan di Indonesia : Studi Tentang Penerapan Ketentuan Corporate Social Responsibility Pada Perusahaan Multi Nasional, Swasta Nasional dan Badan Usaha Milik Negara. Yogyakarta : Pustaka Pelajar Hasibuan, S.P. (2007). Manajemen Sumber Daya Manusia. Cetakan Sembilan, Jakarta. PT. Bumi Aksara.

Prayuginingsih, H., Santosa, T. H., \& Arifin, S. (2011). Pengaruh Motivasi Dan Kepuasan Kerja Terhadap Kinerja Buruh Wanita di Gudang Tembakau Tempu Rejo Kecamatan Pakusari Kabupaten Jember. Agritech, 13(1). 


\section{Jurnal Ilmiah Manajemen dan Bisnis}

Mundakir., dan Zainuri, (2018) Pengaruh Kompensasi dan Motivasi Terhadap Kinerja Pegawai Negeri Sipil dengan Kepuasan Kerja Sebagai Variabel Intervening.

Nugroho, Wahyu, (2009). Pengaruh Kepuasan Kerja terhadap Komitmen Organisasi pada Karyawan Kontrak Universitas Islam Negeri (UIN) Malang, FE UIN Maulana Malik Ibrahim, Malang.

Rahmatullah, (2012), Kedisiplinan dan Ketegasan. Fakultas Ekonomi, Bandung Sugiyono, (2016), Metode Penelitian Kuantitatif, Kualitatif, dan $R$ \& D, Bandung: Alfabeta

Suharsimi, Arikunto, (2002). Prosedur Penelitian, Suatu Pendekatan Praktek. Jakarta : PT. Rineka Cipta.

Suwardi, (2011). Pengaruh Motivasi Kerja, Kepuasan Kerja dan Komitmen Organisasional terhadap Kinerja Pegawai. Jurnal Analisis Manajemen, 5(1).

Wibowo. (2014). Manajemen kinerja. Jakarta: PT Rajagrafindo Persada

Widodo Sri. (2016). Manajemen Sumber Daya Manusia: Teori, Perencanaan Strategi, Isu-isu Utama dan Globalisasi, Manggu Media, Bandung

Yukl, Gary, (2009), Kepemimpinan dalam Organisasi, alih bahasa Jusuf Udaya, Prenhallindo, Jakarta.

Suputra Alit Gusti, Dewi Manuati IG.A., Sudibya Adnyana Gede, (2016). Pengaruh Kepuasan Kerja, Dukungan Organisasional, dan Gaya Kepemimpinan Transformasional terhadap Motivasi Kerja Karyawan di Bank Mandiri, Tbk. E-Jurnal Ekonomi dan Bisnis Universitas Udayana, 5(1) 29-62.

Januari Ismi Cindi, Utami Nayati Hamidah, Ruhana Ika, (2015). Pengaruh Penilaian Kinerja Terhadap Kepuasan Kerja dan Prestasi Kerja (Studi pada Karyawan PT. Telekomunikasi Indonesia, Tbk
Wilayah Malang). Jurnal Administrasi Bisnis (JAB), 24(2).

Karomah Giswi Nurul, Aldiansyah, (2019). Kompensasi terhadap Kinerja Karyawan di PT. Tri Dharma Pusaka Jakarta Selatan. Jurnal Lentera Bisnis, $8(1), 30-49$

Fachreza, Musnadi Said, Abd Majid Shabri M, (2018). Pengaruh Motivasi Kerja, Lingkungan Kerja, dan Budaya Organisasi terhadap Kinerja Karyawan dan Dampaknya pada Kinerja Bank Aceh Syariah di Kota Banda Aceh. Jurnal Magister Manajemen, Fakultas Ekonomi dan Bisnis Unsyiah, pp. 115122.

Setiawan Cahaya Kiki, (2015). Pengaruh Motivasi Kerja terhadap Kinerja Karyawan Level Pelaksana di Divisi Operasi PT. PUSRI Palembang. PSIKIS-Jurnal Psikologi Islam, 1(2),4353

Daryanti Darti, Rohanda, Sukesih, (2013). Pengaruh Motivasi Kerja terhadap Kinerja Pegawai di Badan Perpustakaan, Arsip dan Dokumentasi (BPAD) Propinsi Bengkulu. Vol. 1, No. 2, hlm. 127-135.

Saputri Tri Laras, Fudholi Achmad, Sumarni, (2014). Pengaruh Motivasi Kerja dan Budaya Organisasi terhadap Kinerja Karyawan. Jurnal Manajemen dan Pelayanan Farmasi, 4(1), 63-68.

Damayanti Riski, Hanafi Agustina, Cahyadi Afriyadi, (2018). Pengaruh Kepuasan Kerja terhadap Kinerja Karyawan (Studi Kasus Karyawan Non Medis RS Islam Siti Khadijah Palembang). Jurnal Ilmiah Manajemen Bisnis dan Terapan, 2, 75-86.

Kristianto Dian, (2011). Pengaruh Kepuasan Kerja terhadap Kinerja Karyawan dengan Komitmen Organisasional sebagai Variabel Intervening (Studi pada RSUD Tugurejo Semarang). Jurnal Bisnis Strategi,20(1) 52-63. 


\section{Jurnal Ilmiah Manajemen dan Bisnis}

Cravens, KS., EG. Oliver, S. Oishi \& JS. Stewart. (2015). Workplace Culture Mediates Performance Appraisal Effectiveness and Employee Outcomes: A Study in a Retail Setting, Journal of Management Accounting Research , 27(2).

Cardy, R. L. (2004). Performance Management: Concepts, Skills, and Exercises, Armonk, NY: M. E. Sharpe Djastuti, Indi. (2010). The Influence of Job Characteristics on Job Satisfaction, Organizational Commitment, and Managerial Performance: A Study on Construction Companies in Central Java, Integritas Jurnal Manajemen Bisnis, 3(2).

Jimoh, A.M., (2008), "Emotional Labour, Conscientiousness and Job Tenure as Predictors of Job Performance Among University Administrative Workers in Southwestern Nigerian", International Journal of African \& African American Studies 7(2).

Gunawan Alesander Delvin, Mujanah Siti, Murgiyanto, (2018). Pengaruh Hubungan Interpersonal, Lingkungan Kerja, dan Perceived Organizational Support terhadap Motivasi Kerja dan Kinerja Karyawan pada PT. Mitra Surya Persada. Jurnal Global 02(2) 1122. 